\title{
Faktor yang Berhubungan dengan Kunjungan Voluntary Counsaling and Testing Pada Lelaki Seks Lelaki di Kota Padang
}

\author{
Nurlindawati ${ }^{1}$, Hardisman ${ }^{2}$, Amel Yanis $^{3}$
}

\begin{abstract}
Abstrak
Layanan VCT (Voluntary Counsaling and Testing) atau dikenal dengan pelayanan konseling dan testing HIV adalah upaya menegakkan diagnosis HIV/AIDS untuk mencegah sedini mungkin terjadinya penularan atau peningkatan HIV/AIDS. Lelaki Seks dengan Lelaki (LSL) menjadi penyumbang terbesar dalam penularan HIV/AIDS. Tujuan: Menentukan faktor-faktor yang berhubungan dengan kunjungan VCT pada LSL di Kota Padang. Metode: Penelitian ini merupakan cross sectional study. Besar sampel adalah enam puluh satu (61) responden yang diambil secara accidental sampling. Pengumpulan data dilakukan dengan wawancara menggunakan kuesioner. Data dianalisis secara univariat, bivariat menggunakan Chi-square dan multivariat menggunakan uji regresi logistik. Hasil: Penelitian menunjukkan bahwa waktu lama menjadi seorang LSL diatas 10 tahun (45,9\%), waktu terakhir melakukan kunjungan VCT > tahun 2019 (59,0\%), tempat terakhir melakukan kunjungan VCT di puskesmas (52,5\%), responden melakukan kunjungan VCT minimal tiga bulan terakhir sejak penelitian ini dilakukan (59,0\%), uji Chi-square menunjukkan bahwa variabel yang berhubungan secara signifikan dengan kunjungan VCT adalah keyakinan mengenai VCT $(p=0,005)$, dorongan orang lain $(p=0,001)$. praktik organisasi $(p=0,001)$, nilai mengenai manfaat VCT tidak mempunyai hubungan signifikan. Simpulan: Dorongan dari orang lain tentang VCT merupakan variabel yang mempunyai pengaruh paling signifikan dibanding variabel lainnya.
\end{abstract}

Kata kunci: HIV/AIDS, laki-laki seks dengan laki-laki (LSL), kunjungan VCT

\begin{abstract}
VCT (Voluntary Counseling and Testing) services, otherwise known as HIV testing and counseling services are efforts to establish a diagnosis of HIV / AIDS to prevent the transmission or increase of HIV / AIDS as early as possible. Men of Sex with Men (MSM) are the biggest contributors to HIV / AIDS transmission. Objectives: To determined factors were associated with VCT visits to MSM in Padang City. This research was a cross sectional study. Methods: The samples size were 61 respondents was taken by accidental sampling. Data collection was done by interviewing using a questionnaire. Data were analyzed by univariate, bivariate using Chi-square and multivariate using logistic regression test. Results: The length of time being a MSM was over 10 years (45.9\%), the last time doing a VCT visit> Year 2019 (59.0\%), the last place had a VCT visit at the Publich health(52.5\%), respondents did VCT visits at least the last three months since the study was conducted (59.0\%), the Chi-square test showed that the variables significantly associated with VCT visits were beliefs regarding VCT $(p=0.005)$, encouragement from others $(p=$ 0.001). organizational practice $(p=0.001)$, the value of the benefits of VCT does not have a significant relationship. Conclusions: The encouragement from others about VCT was the variable that had the most significant influence compared to others.
\end{abstract}

Keywords: HIV / AIDS, men sex with men (MSM), VCT visits 
Affiliasi penulis: 1. Prodi Magister Kesehatan Masyarakat Fakultas Kedokteran Universitas Andalas Padang (FK Unand), 2. Bagian IImu Kesehatan Masyarakat FK Unand 3. Bagian Psikiatri FK Unand Korespondensi: Hardisman, Email: hardisman@med.unand.ac.id Hp: 081338070643

\section{PENDAHULUAN}

Human Immunodeficiency Virus (HIV) adalah virus penyebab Aqcuired Immune Deficiency Syndrome AIDS). AIDS merupakan kumpulan gejala penyakit akibat penurunan sistem imun tubuh yang disebabkan oleh virus HIV. ${ }^{1}$

United Nations Programme on HIV/AIDS (UNAIDS) melaporkan bahwa di seluruh dunia pada tahun 2017 terdapat 36,9 juta orang yang hidup dengan HIV, 1,8 juta di antaranya adalah anak-anak berusia di bawah 15 tahun dan orang dewasa sejumlah 35,1 juta penderita. ${ }^{2}$

Surveilans Terpadu Biologis dan Perilaku (STBP) tahun 2013 menyatakan prevalensi HIV pada LSL sebanyak $21 \%$ dari total populasi kunci di Indonesia. Angka ini semakin besar bila tidak ditanggulangi dengan komprehensif. Kementerian Kesehatan (Kemenkes RI) mencatat dari bulan Januari sampai Maret 2018 jumlah kasus HIV yang melapor sebanyak 10.509 orang. $^{3}$

Provinsi Sumatra Barat menempati urutan ke13 dari 34 Provinsi yang tersebar di Indonesia dengan jumlah kasus HIV/AIDS, sejak 1987 hingga 2018 mencapai 3.916 kasus dengan total kematian sebesar $29,6 \%{ }^{4}$

Kota Padang sebagai ibu Kota Provinsi merupakan daerah dengan angka HIV/AIDS tertinggi di Sumatera Barat. Dinas Kesehatan Kota Padang mencatat bahwa terjadi peningkatan kasus setiap tahunnya, hingga Maret 2018 jumlah kumulatif kasus pada tahun 2013 sebanyak 164 kasus, tahun 2014 sebanyak 225 kasus, tahun 2015 sebanyak 207 kasus, 2016 sebanyak 300 kasus, 2017 sebanyak 370 kasus dan 2018 sebanyak 447 kasus diantaranya 352 penderita berjenis kelamin pria dan 95 penderita berjenis kelamin wanita. Menurut kelompok risiko pada tahun 2018 adalah kelompok LSL yaitu 185 orang, kelompok lain-lain terdapat 95 orang, pasangan risiko tinggi terdapat 56 orang, Pelanggan Penjaja Seks (PS) terdapat 33 orang, penderita TB terdapat 27 orang, Waria terdapat 6 orang, Wanita Penjaja Seks
(WPS) terdapat 12 orang, IDU (Injecting Drug Users) terdapat 12 orang dan lbu hamil terdapat 2 orang, WBP terdapat 1 orang, IMS terdapat 2 orang, kandida 8 orang, dan diare 8 orang. ${ }^{5}$

Prostitusi atau Wanita Pekerja Seks (WPS) dan Lelaki Seks Lelaki (LSL) menjadi penyumbang terbesar dalam penularan HIV/AIDS. Klinik Voluntary Counsaling and Testing (VCT) merupakan gerbang utama guna memperoleh informasi mengenai HIV/AIDS, melakukan praktik counsaling dan tes pencegahan dan pelayanan bagi ODHA, sehingga dengan adanya pemanfaatan klinik VCT oleh LSL diharapkan dapat meminimalisir penularan HIV/AIDS. Sebagai salah satu populasi berisiko tinggi, LSL merupakan pengunjung klinik VCT dengan presentase terbanyak di Kota Padang pada tahun 2018. Sampai saat ini belum banyak diketahui prevalensi LSL yang melakukan kunjungan VCT. ${ }^{6}$

Perilaku kehidupan sehari-hari LSL, maka terdapat beberapa faktor yang berhubungan dengan kunjungan VCT dalam upaya pencegahan dan penanggulangan HIV dan AIDS. $L$ Green dalam Notoatmodjo (2010) mengatakan bahwa terdapat predisposing (keyakinan, nilai, motivasi), reinforching (sikap dan perilaku petugaskesehatan, keluarga, pasangan, atasan dII) dan enabling factor (ketersediaan sumber daya, aksebilitas) yang berhubungan dengan perilaku individu, kelompok atau komunitas. $^{7}$

Ada banyak faktor yang berhubungan dengan perilaku LSL dalam melakukan kunjungan VCT, maka penulis tertarik melakukan penelitian mengenai faktorfaktor yang berhubungan dengan kunjungan VCT pada Lelaki Seks Lelaki (LSL).

\section{METODE}

Jenis penelitian ini adalah studi observasional dengan pendekatan cross sectional. Penelitian dilakukan di Kota Padang dari bulan Februari sampai Juni 2019. Populasi penelitian ini adalah Lelaki Seks Lelaki di Kota Padang berjumlah 1308 orang. Sampel penelitian ini adalah 61 LSL yang diambil berdasarkan perhitungan menggunakan rumus Lameshow. Kriteria inklusi dari responden yaitu merupakan LSL yang didata oleh Dinas Kesehatan Kota Padang. Analisis data menggunakan uji Chi-square dan regresi logistik. 
HASIL

Tabel 1. Distribusi frekuensi sosiodemografi LSL di Kota Padang

\begin{tabular}{llcl}
\hline Karakteristik & & (n=61) & $\%$ \\
\hline Umur & $<$ 29 Tahun & 38 & 62,3 \\
& $\geq$ 30 Tahun & 23 & 37,7 \\
Status & Tidak/Belum menikah & 50 & 82,0 \\
Perkawinan & Menikah & 9 & 14,8 \\
& Cerai Hidup/Cerai Mati & 2 & 3,30 \\
Tingkat & Tamat / Tidak Tamat SD & 1 & 1,60 \\
Pendidikan & Tamat SMP & 16 & 26,2 \\
& Tamat SMA & 38 & 62,3 \\
& Tamat PT/Akademik & 6 & 9,80 \\
\hline
\end{tabular}

Tabel 1 menunjukkan bahwa pelaku LSL di Kota Padang tersebar dari berbagai umur, tingkat pendidikan dan perkawinan. Karakteristik demografi pelaku LSL berdasarkan umur lebih dari separuh (62,3\%) dibawah 29 tahun, dan (37,7\%) di atas 30 tahun. Para pelaku lebih dari separuhnya belum menikah $(82,0 \%)$ dan masih ada (14,8\%) diantaranya masih berkeluarga, serta $(3,30 \%)$ sudah cerai hidup/cerai mati. Lebih dari separuhnya (62,3\%) mereka berpendidikan terakhir menengah (SLTA), diikuti oleh mereka tamat SMP $(26,2 \%)$, bahkan tamat PT/Akademi (9,80\%).

Tabel 2. Distribusi frekuensi kunjungan VCT di Kota Padang

\begin{tabular}{lllr}
\hline \multicolumn{2}{c}{ Distribusi Frekuensi } & (n=61) & \% \\
\hline Lama Sebagai LSL & $<$ 5Tahun & 9 & 14,8 \\
& 5-10 Tahun & 24 & 39,3 \\
& $>10$ Tahun & 28 & 45,9 \\
Waktu Terakhir & $\leq 2015$ & 4 & 6,5 \\
Kunjungan VCT & 2016-2018 & 21 & 34,5 \\
& $\geq 2019$ & 36 & 59,0 \\
Tempat Terakhir & Klinik VCT & 1 & 1,6 \\
melakukan & Swasta & 22 & 36,1 \\
Kunjungan VCT & Rumah Sakit & 32 & 52,5 \\
& Puskesmas & 6 & 9,8 \\
& Tempat Lain & & \\
\hline
\end{tabular}

Berdasarkan lama menjadi LSL, umumnya (45\%) diatas 10 tahun dan (39,3\%) pada rentang antara 5-10 tahun. Terakhir melakukan kunjungan VCT lebih dari separuhnya (59,0\%) di atas tahun 2018, rentang antara tahun 2016-2018 (34,5\%), dan di bawah tahun 2016 (6,5\%). Tempat terakhir LSL melakukan kunjungan VCT di Puskesmas (52,5\%), Rumah Sakit (36,1\%), Klinik VCT Swasta $(1,6 \%)$ dan di tempat lain $(9,8 \%)$.

Tabel 3. Hubungan keyakinan, nilai, dorongan dan praktik organisasi dengan kunjungan VCT pada LSL di Kota Padang

\begin{tabular}{lccccc}
\hline \multicolumn{2}{c}{ Variabel } & $(\mathbf{n = 6 1 )}$ & $\%$ & $\mathbf{p}$ & OR \\
\hline Keyakinan & Baik & 35 & 67,3 & 0,005 & 16,471 \\
& Tidak & 1 & 11,1 & & $(1,903-$ \\
Nilai & & & & & $142,527)$ \\
& Baik & 27 & 69,9 & 0,201 & 2,357 \\
& Tidak & 9 & 45,0 & & $(0,791-$ \\
Dorongan & Baik & 33 & 84,6 & 0,001 & 34,833 \\
& Tidak & 3 & 13,6 & & $(7,800-$ \\
& & & & & $155,557)$ \\
Praktik & Baik & 33 & 71,7 & 0,001 & 10,154 \\
Organisasi & Tidak & 3 & 20,0 & & $(2,458-$ \\
Klinik VCT & & & & & $41,950)$ \\
\hline
\end{tabular}

Berdasarkan Tabel 3 dapat dilihat bahwa keyakinan secara umum berada pada kategori baik yaitu $85,2 \%$, hasil uji Chi-square menunjukkan terdapat hubungan yang bermakna antara keyakinan dengan kunjungan VCT pada LSL $(p=0,005)$. Hasil analisis juga menunjukkan bahwa responden yang memiliki keyakinan yang baik berpeluang 16,471 OR= (1,903-142,527) kali untuk melakukan kunjungan VCT dibandingkan mereka yang memiliki keyakinan yang kurang baik tentang VCT. Nilai mengenai manfaat VCT secara umum berada pada kategori baik yaitu 69,9\%. Hasil uji Chi-square menunjukkan bahwa tidak terdapat hubungan yang bermakna antara nilai dengan kunjungan VCT pada LSL $(p=0,201)$.

Dorongan secara umum berada pada kategori baik yaitu $84,6 \%$, hasil uji Chi-square menunjukkan terdapat hubungan yang bermakna antara dorongan dengan kunjungan VCT pada LSL $(p=0,001)$. Berdasarkan hasil analisis juga menunjukkan bahwa responden yang memiliki dorongan yang baik berpeluang 34,833 OR= (7,800-155,557) kali untuk melakukan kunjungan VCT dibandingkan mereka yang kurang mendapatkan dorongan dari orang lain tentang VCT. 
Praktik organisasi klinik VCT secara umum berada pada kategori baik yaitu $71,7 \%$, hasil uji ChiSquare menunjukkan terdapat hubungan yang bermakna antara praktik organisasi Klinik VCT dengan kunjungan VCT pada LSL $(p=0,001)$. Berdasarkan hasil analisis juga menunjukan bahwa responden yang mendapatkan pelayanan yang baik dari klinik organisasi VCT berpeluang 10,154 OR $=(2,458$ 41,950) kali untuk melakukan kunjungan VCT dibandingkan mereka yang kurang mendapatkan pelayanan dari Klinik organisasi VCT tentang VCT.

Tabel 4. Faktor determinan kunjungan VCT pada LSL di Kota Padang

\begin{tabular}{llll}
\hline Variabel & $\mathbf{p}$ & Exp (B) & OR \\
\hline Dorongan & 0,001 & 39,190 & $(7,274-211,132)$ \\
Praktik Organisasi & 0,008 & 12,287 & $(1,930-78,231)$ \\
Klinik VCT & & & \\
\hline
\end{tabular}

Berdasarkan Tabel 4 diatas, dapat dilihat bahwa variabel dorongan $(p=0,001)$ yang menjadi faktor determinan utama kunjungan VCT dan berpeluang 39,190 (OR=7,274-211,132) kali untuk melakukan kunjungan VCT.

\section{PEMBAHASAN}

Sebagian besar responden pada penelitian ini berusia dibawah 29 tahun dan belum menikah, dengan tingkat pendidikan tamat SMA. Secara umum lama responden menjadi LSL di atas 10 tahun.

Hasil analisis menunjukkan bahwa ada hubungan antara keyakinan dengan kunjungan VCT pada LSL $(p=0,005)$, didapatkan nilai $O R=16,471$ yang artinya responden yang mempunyai keyakinan baik mengenai VCT cenderung 16.471 kali melakukan kunjungan VCT dibandingkan dengan responden yang mempunyai keyakinan yang kurang baik. Hasil ini senada dengan penelitian Widiyanto (2009), yang menyatakan ada hubungan yang signifikan antara keyakinan dengan kunjungan VCT dengan $p=0,000$. Penelitian ini menunjukkan bahwa semakin baik keyakinan responden mengenai manfaat VCT maka ia akan melakukan kunjungan VCT dengan rutin. ${ }^{8}$

Menurut Green dalam Notoatmodjo (2010), keyakinan merupakan salah satu faktor predisposing dalam membentuk perilaku kesehatan seseorang.
Keyakinan adalah pendirian responden yang meyakini bahwa konseling dan testing HIV akan memberikan manfaat pada diri responden. ${ }^{7}$

Ada hubungan antara dorongan orang lain dengan kunjungan VCT pada LSL $(p=0,001)$, didapatkan nilai $\mathrm{OR}=34,833$. Responden yang mendapatkan dorongan yang baik dari orang lain mengenai VCT cenderung 34,833 kali melakukan kunjungan VCT dibandingkan dengan responden yang kurang mendapatkan dorongan dari orang lain. Hasil ini didukung oleh penelitian yang dilakukan oleh Purwaningsih et al (2011), menyatakan bahwa 52\% responden merasakan adanya faktor pendorong yang kuat. ${ }^{9}$ Faktor pendorong tersebut berupa dukungan dari teman-teman dan keluarga serta petugas kesehatan/dokter untuk melakukan VCT. Dorongan dari petugas lapangan yang didapatkan oleh responden melalui pemberian informasi untuk menimbulkan pemahaman dan kesadaran. Petugas lapangan selalu mengingatkan pada setiap bulan dan selalu memberi paparan informasi.

Menurut Green dalam Notoatmodjo (2010), sebuah dukungan /dorongan merupakan contoh faktor reinforcing sangat berpengaruh dalam suatu perilaku. Selain dari teman sesama LSL, dorongan juga dapat diperoleh dari penjangkau lapangan dan petugas

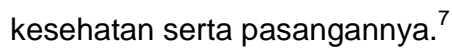

Ada hubungan antara praktik klinik organisasi VCT dengan kunjungan VCT pada LSL $(p=0,001)$, didapatkan nilai $\mathrm{OR}=10.154$ yang artinya responden yang mendapatkan pelayanan klinik VCT yang baik cenderung 10.154 kali melakukan kunjungan VCT dibandingkan dengan responden yang mendapatkan pelayanan klinik VCT yang kurang baik. Hasil ini sesuai dengan hasil penelitian Azinar dan Maskuniawan (2018), bahwa ada hubungan signifikan layanan kesehatan tes HIV dengan praktik tes HIV didapat nilai $p$-value $0,024 .^{10}$

\section{SIMPULAN}

Faktor yang memiliki hubungan bermakna dengan kunjungan VCT pada LSL di Kota Padang adalah keyakinan mengenai VCT, dorongan yang diterima dari orang lain dan praktik organisasi klinik VCT, sedangkan nilai tidak mempunyai hubungan yang bermakna terhadap kunjungan VCT. Variabel 
yang paling dominan berhubungan dengan perilaku kunjungan VCT pada LSL di Kota Padang adalah variabel dorongan yang diterima dari orang lain mengenai manfaat VCT.

\section{SARAN}

Dinas Kesehatan hendaknya meningkatkan informasi dan edukasi tentang kunjungan VCT dan pesan kesehatan lainnya untuk meningkatkan dorongan yang baik pada LSL, mengoptimalkan peran tenaga kesehatan dalam promosi kesehatan, konseling serta tes HIV, pendekatan terhadap populasi berisiko, agar mereka semakin terdorong dan termotivasi untuk rutin melakukan kunjungan VCT.

\section{UCAPAN TERIMAKASIH}

Terimaksih kepada pihak Dinas Kesehatan Kota Padang, Kepala Puskesmas dan Tenaga Kesehatan yang telah memberikan pengetahuan, serta semua pihak yang terlibat dalam menyelesaikan penelitian ini.

\section{DAFTAR PUSTAKA}

1. Widiyanto FC, Triwibowo C. Trend disease trend penyakit saat ini. Jakarta: Trans Info Media; 2013.hlm.110.

2. UNAIDS. UNAIDS data 2017. Geneva: UNAIDS. 2017.hlm.1.
3. Kementerian Kesehatan Republik Indonesia (Kemenkes RI). Surveilans terpadu biologis dan perilaku. Jakarta: Kemenkes RI; 2013.hIm. 2.

4. Kemenkes RI. Laporan perkembangan HIV-AIDS \& infeksi menular seksual (IMS) triwulan 1 tahun 2018. Jakarta: Direktorat Jendral Pencegahan dan Pengendalian Penyakit. 2018.hlm.1.

5. Dinas Kesehatan Kota Padang. Laporan Tahunan Kesehatan Kota Padang. Padang: Dinas Kesehatan Kota Padang; 2018.

6. Hardisman, Firdawati, Sulrieni NI. Model determinan perilaku "lelaki seks lelaki" di kota Padang Sumatera Barat. Jurnal Kesehatan Andalas. 2018;7(3):305-13.

7. Notoatmodjo S. IImu perilaku kesehatan. Jakarta: PT Rineka Cipta; 2010.hlm.16-7.

8. Widiyanto G. Faktor-faktor yang Berhubungan dengan praktik wanita pekerja seks (WPS) dalam VCT ulang di Lokalisasi Sunan Kuning Kota Semarang [tesis]. Semarang: Prodi Magister Fakultas Kesehatan Masyarakat Promosi Kesehatan Universitas Diponegoro; 2009.

9. Purwaningsih, Misutarno, Imamah SI. Analysis factor related to VCT utilization for the high risk person of HIV/AIDS. Jurnal Ners dan Kebidanan. $2011 ; 6(1): 58-67$.

10. Azinar M, Maskuniawan. Faktor-faktor yang berhubungan dengan praktik tes HIV pada waria pekerja seks di kota Semarang. Journal of Health Education. 2018;3(1):7-16. 